\title{
NOTES ON OXYGEN SAMPLING ON THE FLADEN GROUND
}

\author{
By John H. STeELe \\ The Marine Laboratory, Aberdeen
}

(Text-fig. I)

For the years $195 \mathrm{I}-53$ sampling of phosphate concentration has been used to describe the plant production on the Fladen Ground (Steele, 1956). Further studies in 1955-56 have compared the phosphate sampling with the ${ }^{14} \mathrm{C}$ technique (Steele, 1957). On most occasions samples were also taken for dissolved oxygen concentration and these notes discuss some attempts made to interpret those data. A set of oxygen profiles for Fladen are shown in the earlier paper.

There are four main causes of change in oxygen concentration; two physical, water mixing and surface exchange; and two biological, increase due to photosynthesis and decrease due to the breakdown of organic matter and to respiration. Except for surface exchange, these effects should have concomitant changes in the phosphate concentration and the main problems arise through the attempts to compare them.

When studying the phosphate data, the amount of vertical mixing was estimated from temperature profiles and its effect subtracted from the observed phosphate changes between two dates to leave what was called the 'biological change'. The same procedure can be carried out for the oxygen data except for the 0-20 m layer where an estimate of surface exchange is required before the biological change can be found. A fairly successful attempt to estimate exchange was made by Redfield (1948), using a formula which states in effect that the rate of exchange is proportional to the difference between the surface concentration and the equilibrium concentration. For Fladen, the best available oxygen data are those for 1953, when two stations were worked at fairly regular intervals and the computations of 'biological change' and surface exchange were made for these data. The values for oxygen solubility used in Redfield's formula were taken from the nomogram given by Richards \& Corwin (1956), which is based on the data of Truesdale, Downing \& Lowden (1955).

To compare these calculations with the similar ones for phosphate, a conversion factor is necessary, and one is given by Sverdrup, Johnson \& Fleming (1942, p. 237). This depends on the phosphorus/carbon ratio found by chemical analysis of plankton and on an association of carbon and oxygen in the form $\mathrm{CO}_{2}$. The numerical value in the usual units is

I $\mu \mathrm{g}$ atom phosphorus $\equiv 2 \cdot 36 \mathrm{ml}$. oxygen. 
However, when this factor was used it was found that in the region below $40 \mathrm{~m}$, where the 'biological changes' showed an increase for phosphate and a decrease for oxygen, the phosphate gain was equivalent to approximately two-thirds of the oxygen loss.
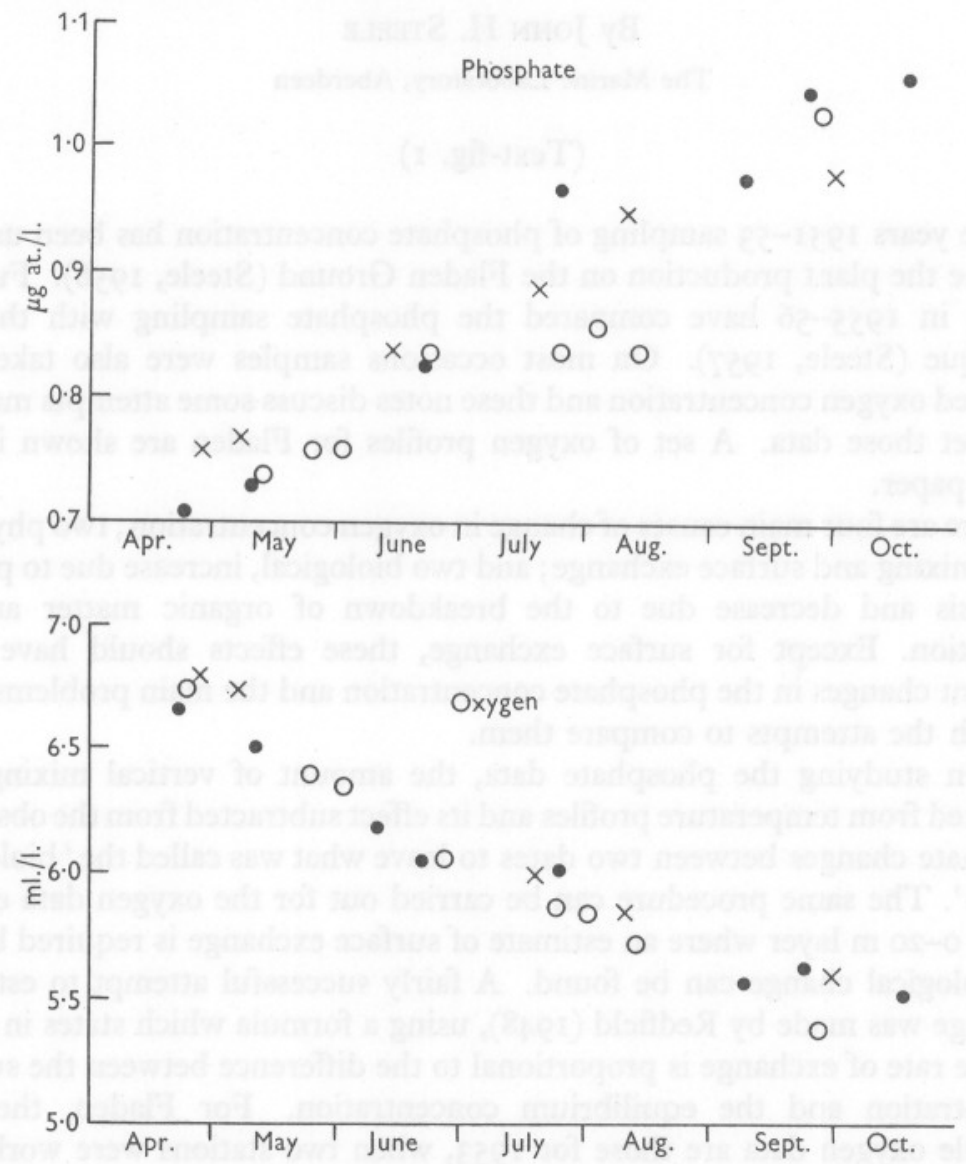

Fig. I. The near-bottom concentrations of phosphate and oxygen for the years $1953(\bullet)$, $1955(O)$ and $1956(x)$.

To check this feature independently of the calculation, the oxygen and phosphate changes can be compared directly for the water below the thermocline which remains unmixed from April to October. In Fig. I, the nearbottom concentrations are plotted for the years 1953,1955 and 1956 . There is considerable variability in the values, especially the phosphate, but the general rates of change seem to be consistent from year to year. These rates give a conversion factor of

I $\mu$ g atom phosphorus $\equiv 3.87 \mathrm{ml}$. oxygen. 
The increase confirms the results of the calculations and the explanation probably lies in the fact that the basis of the oxygen/carbon comparison was a carbohydrate metabolism.

It has been shown that Calanus finmarchicus probably have a protein content of about 50\% (Marshall, Nicholls \& Orr, 1934) which would lead to a higher oxygen/phosphate ratio. In a full discussion of this problem Riley (I95I) deduced that with a protein content of $68 \%$, the metabolism of zooplankton and their bacterial oxidation would give a ratio approximately double the value given by Sverdrup et al. (1942). For phytoplankton it has usually been found that the photosynthetic quotient is nearly unity, which would entail a carbohydrate metabolism and so require the earlier conversion factor. However, Cramer \& Myers (I948) have obtained a quotient of I.47, and they believe that the previous values are due to a temporary shift to carbohydrate synthesis caused by the high light intensities required in the experiments (see also Ryther, 1956). Their results would lead to a conversion factor of 3.5 which is near the value given by the Fladen data. For these reasons, a conversion factor of about 3.87 may be applicable not only in the lower waters but also in the euphotic zone, and this value is used in the following comparison.

The biological changes in phosphate and oxygen are compared by converting the phosphate changes to oxygen units and then adding these to the calculated oxygen changes. What is left over will be termed the 'residual' thus:

residual $=$ oxygen change +3.87 phosphate change.

If the phosphate changes always corresponded to oxygen changes then the residuals would be zero except for the $0-20 \mathrm{~m}$ layer where they would be balanced by the surface exchange. Such agreement is not found and the values for the various factors are given in Table $\mathrm{I}$.

The first point to be noted is that the estimates of surface exchange are greater than the residuals for $0-20 \mathrm{~m}$ by a factor which varies from $\mathrm{I} \cdot 05$ to $8 \cdot 8$. Thus the formula does not appear to be successful in this case. Below $20 \mathrm{~m}$ the residuals are very variable, and all that can be said is that in general they are less than the oxygen changes; the few cases in which the oxygen changes have been accentuated, are printed in bold type.

Another problem concerning oxygen:phosphate ratios arises from results given by Riley (1956). By similar methods to those used for the Fladen data, he estimated the biological changes of oxygen and phosphate in Long Island Sound. He found that the over-all ratios for production were normal but the phosphate was absorbed at a lower level than the oxygen was produced. On Fladen, in the 20-30 m layer, this occurs to some extent in the spring but not in the summer (Table I). However, it is the summer that is of most interest since at this time the phosphates show maximum production in the $20-30 \mathrm{~m}$ layer. Direct observations of this feature are available for one particular time interval, 2I June-24 July 1953, when there was very little mixing at or below 
$30 \mathrm{~m}$. During this period the average changes at $30 \mathrm{~m}$ for four stations were: temperature, $+0.25^{\circ} \mathrm{C}$; phosphate, $-0.19 \mu \mathrm{g}$ at. $/ 1$; oxygen, $+0.98 \mathrm{ml}$. $/ 1$. In fact the oxygen increase is greater than that required by the phosphate decrease, so it would seem that the rate of production was at least that indicated by the phosphate data. This case may be peculiar due to the lack of vertical mixing, and later data using ${ }^{14} \mathrm{C}$ (Steele, r957) do not support the phosphate results.

TABLE 1. ESTIMATES OF SURFACE EXCHANGE, 'BIOLOGICAL CHANGE' OF OXYGEN AND RESIDUALS FOR FLADEN IN 1953

\begin{tabular}{|c|c|c|c|c|c|c|c|c|}
\hline \multirow{3}{*}{$\underset{(\mathrm{m})}{\text { Exchange.... }}$} & \multicolumn{2}{|c|}{ 2I. iv. -II. V. } & \multicolumn{2}{|c|}{ II. V.-II. vi. } & \multicolumn{2}{|c|}{ II-2I. vi. } & \multicolumn{2}{|c|}{ 21. vi.-24. vii. } \\
\hline & - & $3 \cdot 36$ & - & $6 \cdot 36$ & - & $I \cdot 52$ & & 3.64 \\
\hline & Ox. & Res. & Ox. & Res. & Ox. & Res. & Ox. & Res. \\
\hline $0-20$ & $I \cdot 62$ & -0.38 & 0.48 & $-\mathbf{I} \cdot 37$ & -0.77 & $-I \cdot 02$ & -0.58 & $-I \cdot 40$ \\
\hline $20-30$ & -0.46 & $-0 \cdot 64$ & $-1 \cdot 26$ & $-2 \cdot 15$ & -0.05 & -0.41 & 0.96 & O.II \\
\hline $30-40$ & -0.14 & -0.50 & -0.60 & 0.72 & -0.32 & -0.22 & 0.44 & 0.01 \\
\hline $40-50$ & -0.38 & 0.01 & -0.31 & -0.23 & -0.36 & -0.03 & 0.04 & 0.53 \\
\hline $50-60$ & -0.28 & -0.05 & -0.24 & -0.13 & -0.26 & 0.04 & 0 & 0.39 \\
\hline \multirow[t]{2}{*}{$60-140$} & -0.86 & -0.17 & $-I \cdot 74$ & 0.46 & $-\mathrm{I} \cdot 74$ & 0.49 & -0.04 & $\mathrm{I} \cdot 80$ \\
\hline & \multicolumn{2}{|c|}{ 24. vii.-8. ix. } & \multicolumn{2}{|c|}{$8-25$. ix. } & \multicolumn{2}{|c|}{ 25. ix.-I9. x. } & & \\
\hline Exchange... & - & 3.87 & - & 0.98 & - & 0.70 & & \\
\hline (m) & Ox. & Res. & Ox. & Res. & Ox. & Res. & & \\
\hline $0-20$ & -2.05 & $-2 \cdot 30$ & -0.91 & -0.93 & 0.49 & -0.30 & & \\
\hline $20-30$ & 0.82 & -0.26 & 0.71 & 0 & 49 & -0.30 & & \\
\hline $30-40$ & $\mathrm{I} \cdot 33$ & $-I \cdot 3 I$ & -0.04 & 0.19 & 0.35 & -0.44 & & \\
\hline $40-50$ & $-I \cdot I 6$ & -0.08 & -0.35 & 0.06 & 0.10 & -0.24 & & \\
\hline $50-60$ & -0.58 & -0.35 & -0.20 & 0.32 & -0.02 & 0.06 & & \\
\hline $60-140$ & $-4 \cdot 35$ & $-2 \cdot 86$ & 0.28 & $\mathrm{I} \cdot 80$ & -0.64 & 0.74 & & \\
\hline
\end{tabular}

\section{SUMMARY}

A comparison is made of oxygen and phosphate data from the Fladen Ground. It is found that the conversion factor for oxygen:phosphorus given by Sverdrup et al. (I942) does not agree with the changes below the euphotic zone and an alternative factor is calculated. Problems concerning surface exchange and production are also discussed.

\section{REFERENCES}

Cramer, M. \& MYers, J., 1948. Nitrate reduction and assimilation in Chlorella. f. gen. Physiol., Vol. 32, pp. 93-102.

Marshall, S. M., Nicholls, A. G. \& OrR, A. P., 1934. On the biology of Calanus finmarchicus. V. Seasonal distribution, size, weight and chemical composition in Loch Striven in 1933 and their relation to the phytoplankton. F. mar. biol. Ass. U.K., Vol. 19, pp. 793-827.

REDFIELD, A. C., I948. The exchange of oxygen across the sea surface. F. mar. Res., Vol. 7, pp. 347-6r.

RICHARDS, F. A. \& CoRwIN, N., 1956. Some oceanographic application of recent determinations of the solubility of oxygen in sea water. Limnol. Oceanogr., Vol. I, pp. 263-7. 
RILEy, G. A., I95I. Oxygen, phosphate and nitrate in the Atlantic Ocean. Bull. Bingham oceanogr. Coll., Vol. 13, Art. I, 126 pp.

— 1956. Oceanography of Long Island Sound, I952-I954. IX. Production and utilization of organic matter. Bull. Bingham oceanogr. Coll., Vol. 15, pp. 324-44. Ryther, J. H., 1956. The measurement of primary production. Limnol. Oceanogr., Vol. I, pp. 72-84.

Steele, J. H., 1956. Plant production on the Fladen Ground. F. mar. biol. Ass. U.K., Vol. 35, pp. I-33.

1957. A comparison of plant production estimates using ${ }^{14} \mathrm{C}$ and phosphate data. F. mar. biol. Ass. U.K., Vol. 36, pp. 233-4I.

SverdRup, H. U., Johnson, M. W. \& Fleming, R. H., 1942. The Oceans; their Physics, Chemistry and General Biology. I087 pp. New York: Prentice-Hall.

Truesdale, G. A., Downing, A. L. \& Lowden, G. F., 1955. The solubility of oxygen in pure water and sea water. F. appl. Chem., Vol. 5, pp. 53-62. 